\title{
Pena de extrañamiento de Enrique Lihn: La escritura como musa de la calle, el hospital y los museos
}

\author{
Pena de extrañamiento by Enrique Lihn: Writing as a \\ muse of the street, the hospital and museums
}

\section{MarCelo GarRido}

Universidad de Concepción. Concepción, Chile

marcelogarrido@udec.cl

\section{RESUMEN}

El libro de poemas Pena de extrañamiento (1986) de Enrique Lihn, desarrolla y problematiza la experiencia del viaje a través de una escritura fragmentaria y circunstancial. La mirada del poeta va configurando un objeto visual que se relaciona con la cultura tardomoderna de forma reflexivo-marginal, a partir de un desarraigo efectivo.

Palabras claves: Enrique Lihn, subjetividad, poesía, viaje, desarraigo.

\section{ABSTRACT}

Pena de extrañamiento (1986), Enrique Lihn's book of poems, develops the experience of travelling and its discussion through a fragmentary and circumstantial writing. The poet's view sets a visual object related to the culture of the late modernity in a reflexive, marginal form, starting from an effective uprooting.

Keywords: Enrique Lihn, subjectivity, poetry, travelling, uprooting.

Recibido: 21.04.2010

Aceptado: 21.09.2010.

El libro completo, que no llegó a publicar, lleva por título Musa de la calle, el hospital y los museos. Pena de extrañamiento está conformado por poemas que pertenecen a este título mayor. 


\section{EL VIAJE POR LAS POSTRIMERÍAS DEL SER}

Dena de extrañamiento $(1986)^{1}$ se terminó de imprimir el 26 de julio de 1 1986, año de su publicación en Santiago. Otros dos libros de poesía serían publicados en vida del autor: Mester de juglaria (1987) y La aparición de la Virgen (1987). Lo cierto es que $P E$ pone fin a lo que el autor $-y$ también la crítica- ha denominado poesía de viaje ${ }^{2}$. Finaliza, debemos puntualizar, esa poesía que el autor concibe en sus desplazamientos tardíos, a destiempo, por la cultura occidental, principalmente ${ }^{3}$. Viajes, los de Lihn, culturales, de reconocimiento más que de conocimiento cuando tienen como destino el viejo mundo, a diferencia de las visitas a la megalópolis norteamericana, en la que no hay ni conocimiento ni reconocimiento posible. Es el caso de $P E$, libro que actualiza, desarrolla y profundiza la experiencia del tránsito recogida en A partir de Manhattan (1979).

Clave resulta en la poesía de Enrique Lihn la experimentación del viaje en sus formas históricas, pero también existenciales. No el vagabundeo o la errancia como en otros poetas viajeros adscritos a nuestra tradición (Mistral, Huidobro), sino un viaje sujeto a la razón y al extravío modernos, a la lógica histórica y al espacio literario, en definitiva, fuertemente situado. Una beca de museología otorgada por la UNESCO le permite al poeta salir por primera vez de Chile rumbo a París. El registro o documentación de la circunstancia del viaje se transformará en Poesía de paso $(1966)^{4}$ por el que obtendrá el premio Casa de las Américas. Este libro da forma a una configuración específica de su espacio poético: la transitoriedad y la proyección reflexiva del

\footnotetext{
${ }^{1}$ De ahora en adelante $P E$.

${ }^{2} \mathrm{Al}$ ciclo de escritura iniciado con Poesía de paso (1966) se deben agregar: Estación de los desamparados (1982), publicado diez años después de ser escrito; París, situación irregular (1977); A partir de Manhattan (1979), y, por último, el libro que nos proponemos estudiar, Pena de extrañamiento (1986).

${ }^{3}$ Adriana Valdés considera el libro de publicación póstuma Diario de muerte (1989) como su último diario de viaje. "Hace ya tiempo, al escribir un artículo sobre Lihn para el Diccionario Enciclopédico de las Letras de América Latina (DELAL), sugerí que gran parte de su obra podía entenderse en la clave del viaje; no sólo los de títulos o temas tan explícitos como los ya citados, sino también, incluso, su libro póstumo, Diario de muerte, una especie de bitácora de un tránsito hacia la última frontera, la más desconocida" (Valdés, 2008: 90).

${ }^{4}$ Casa de las Américas, Colección Premio La Habana, Cuba, 1966. Con respecto a este libro su autor dice "Poesía de paso es en parte un diario de viaje en que se conservan imágenes de una Europa mitificada, vista por ojos de un provinciano. Pero ya esos temas estaban en el libro anterior (La pieza oscura (1963)). La idea del poeta como extranjero o trashumante, el distanciamiento como forma de aproximación a lo real, "el horror a la vida, el éxtasis de la vida". La postulación de una libertad que pasa por el desasimiento, el afán desmitificador frente a los sentimientos afincados en la moral tradicional" (Fuenzalida, 2005: 34).
} 
identitario americano en relación con lo que el autor llamará el antiorigen 5 . La afectación de la subjetividad-Lihn, enfrentada al deseo de origen, genera una profundidad poética que nos permite evidenciar la naturaleza desarraigada del sujeto americano. Es esta mirada negativa de sí mismo -ahogada y en tensión en La pieza oscura (1963) - la que permite ver esa forma ajena en la que ocurre el escritor latinoamericano, su extranjería; condición que Lihn admite y mediante la cual entra en un diálogo escéptico con la modernidad cultural desde el margen latinoamericano. El viaje real tiene un efecto eufórico ${ }^{6}$ sobre el sustrato existencial del autor, es también una salida de sí mismo, una puesta en condición y circunstancia, que lo enfrenta con un momento decisivo de la historia latinoamericana de mediados del siglo $\mathrm{XX}$, más bien empeñada en la implementación de un proyecto progresista de carácter materialista, que busca arraigar en la base de una sociedad que no acaba -aún- de resolver el origen de su propia naturaleza histórica. El viaje real significa una salida de la pieza oscura del subjetivismo para ir en busca de los objetos que alimentan los supuestos constituyentes del sujeto $y$, a partir de eso, dar espacio a un diálogo fiero con la alta modernidad en los términos de un saber negativo, alterno y sudamericano.

La óptica-poética que moviliza la obra de Lihn -una vez iniciada su poesía de viaje- atraviesa las zonas de peligro abiertas por el proyecto moderno y que ciertamente lo velan. La distancia se transforma, por lo tanto, en elemento esencial, y le permite marginarse críticamente de ese proyecto. Lo anterior tiene como consecuencia la imposibilidad de morar pasivamente en las inmediaciones de esas zonas de peligro. El discurso poético en la forma de postal, diario de viaje o glosa visual posibilita que la subjetividad se evada de los condicionamientos que el proyecto progresista moviliza en el territorio social latinoamericano, que lo experimentan en el contexto del

\footnotetext{
${ }^{5} \mathrm{Al}$ respecto el poeta señala: "Se trata de abarcar ciertos espacios desconocidos en una como tarea de reconocimiento; sí, azar, o sin que la finalidad de ese anti-itinerario sea lo determinante. Una combinación de familiaridad y extrañamiento respecto de los lugares que te recuerdan tu antiorigen. La condición de extranjero me parece a mí particularmente entrañable para el tipo de hispanoamericano al que pertenecemos como personas, por así decirlo, cultas" (Lastra, 1990: 60).

${ }^{6}$ En el libro de entrevistas Isla negra no es una isla (1996), del peruano Edgar O'Hara, Enrique Lihn reflexiona sobre este carácter eufórico de su espacio poético, al respecto señala lo siguiente: “(...) es una especie de espacio imantado en que pueden caer muy distintas cosas (...). No es un condicionamiento temático: es un lugar en el que caen todas las cuestiones y se ordenan de cierta manera. Hay fruición y euforia también. Yo creo que mi poesía da cuenta de la euforia porque insiste mucho en la integración y en la posibilidad de la homología de los distintos niveles del lenguaje...Que las cosas suenen de una manera en la que resuene aquello de lo que se está hablando... Una verdadera retórica en el sentido en que la poética es una retórica. Y hay una conciencia retórica de una poética que es eufórica..." (O’Hara, 1996: 23).
} 
"protectorado utópico"7 que rige el horizonte cultural de la segunda mitad del siglo XX.

En síntesis, la poesía de Enrique Lihn tiene una intensidad que nos permite apreciar, más allá de la complejidad evidente de sus textos, las condiciones que definen el espacio creativo latinoamericano, fuertemente orientado hacia las formaciones sociopolíticas nacionales. De esta ligazón nace una forma discursiva que en términos tradicionales se asimila como un gesto crítico propio de la condición moderna. La reflexión posmoderna es heredera de la demanda totalitaria que domina el pensamiento moderno, un imperativo global que viene en su centro, la universalidad como logro correcto y final de las sociedades humanas. Disimulada en la condición posmoderna, la modernidad es un signo implacable. Con este signo implacable el trabajo creativo-reflexivo de Enrique Lihn mantiene un diálogo, cuyo logos básico es la sospecha, una abierta desazón, pesimismo que no es hijo de la crítica, sino de la contradicción, de la afirmación que se espanta en el enunciado próximo, discurso plagado de fantasmas, de cuerpos en descomposición, de cháchara y metecos, de tetas negras y de menesterosos en el paseo peatonal de una ciudad vigilada por los garantes del mercado en ruinas.

En esta poesía de las postrimerías del ser adquiere especial relevancia la noción de poesía situada ${ }^{8}$ desarrollada por Lihn, en la cual el dato, el recurso intertextual permite al autor generar una transtextualidad que se mueve entre lo histórico y lo existencial. En esa zona aparece una configuración mental que es más una tensión que una oscilación, poniendo en evidencia la necesidad de alcanzar una forma precaria de saber ontológico ante el progresivo embate de la sociedad globalizada, posmoderna.

¿Por qué viaja Enrique Lihn? Más allá de la anécdota ¿Por qué esa insistencia en aclarar la naturaleza real y tardía de sus viajes en oposición al

7 Tal como lo menta el artefacto parriano: "La izquierda y la derecha unidas / jamás serán vencidas" (Parra, 1972).

${ }^{8}$ Esta noción de poesía situada es fundamental en la obra de Enrique Lihn. Al respecto el autor señala lo siguiente: "En otras palabras, yo terminé por instalarme con ese libro(La pieza oscura) -donde ya no hay poemas que no se propongan algún tipo de concreción- en lo literario pero al margen de los distintos tipos de poesía que eluden la interpretación genérica. Me declaré en contra de una 'poesía poética' (...), y a favor de una poesía situada" (Lastra, 1990: 29). Y Más adelante en el mismo libro completa lo anterior de la siguiente forma: "Pero hay algo que liga a la poesía y a lo que en general se escribe en prosa, un elemento que rebasa la cuestión genérica: es la relación de un texto con la situación, y a eso me refería al hablar de poesía situada. (...) En cuanto a mi propia manera de entender la relación texto/situación: cuando escribía los poemas de La pieza oscura había llegado a una cierta altura de mi experiencia que me había hecho descender notoriamente de la estratósfera; y ese descenso se resolvió en los poemas como una instancia de desidealización, desromantización, escepticismo" (Lastra, 1990: 29). 
carácter imaginario, asociado tradicionalmente al trabajo literario? ¿Por qué viaja Lihn y por qué la obsesión con el registro? ¿Qué relación surge entre el lenguaje y el viaje? Fernando Pérez Villalón (2004), en los párrafos iniciales de su reflexión sobre el viaje y los viajeros, produce interesantes ideas sobre la naturaleza del viaje literario en Latinoamérica. Pérez Villalón constata en este estudio que nuestro continente, y en general el nuevo mundo, ingresa en la historia y cultura de Occidente de la mano de un tipo particular de sujeto. Este tipo específico, que podría ser definido a grandes rasgos como una máquina de exploración y conquista, se ubica en el origen de lo americano; es, por así decirlo, una presencia y una sombra insoslayable, cuya acción es, en nuestro devenir histórico, definitiva. Con acierto, señala el autor que el viaje de exploración entre los siglos XVI y XIX consiste en la aniquilación sistemática de la diferencia. El deseo de aniquilación del otro, como proyecto, deja una marca que inscribe, en el origen de lo que será Latinoamérica, la maternidad del desarraigo. Desarraigo que tomará todas las configuraciones posibles y que viene a ser una fuente inagotable de nuestra naturaleza ontológica. No insistiremos en esto, pero aceptando estas consideraciones, debemos constatar que el viaje posee para los escritores latinoamericanos un significado ciertamente trágico y no tan épico como se quisiera y como se quiere asimilar en la perspectiva de nuestros exitosos exiliados a los que se agradece uno que otro reconocimiento internacional. El viaje se relaciona más bien con la puesta en cuestión de la potencia ontológica, desde siempre contradictoria y en constante deseo de sí misma.

Según señala Pérez Villalón en su estudio, actualmente la forma del viaje se presenta en retirada:

No se viaja, simplemente hay desplazamientos. El viaje suponía un grado de incertidumbre, no en las condiciones o posibilidades de supervivencia, pero sí en la consistencia del lugar al que el hombre se dirigía (Pérez Villalón, 2004: 48-49).

La época que describe esta reflexión es la que conocemos como capitalismo cultural en la que la experiencia extrema del viaje está administrada no por el azar, sino por los servicios de un contrato específico pactado en el marco de una cómoda relación comercial. De esta forma "(E)l turista da una vuelta, un tour, en el que todo puede ser anticipado. Cada instante de su viaje ha sido planificado minuciosamente con antelación" (Pérez Villalón, 2004: 49). El turista, a diferencia del viajero, renuncia al riesgo en beneficio de las comodidades de la vida moderna. En muchos aspectos, el viaje del 
escritor latinoamericano sigue siendo ese riesgo revelador y necesario para la composición de lugar, para la transformación de la lengua, para la toma de realidad ejecutada, toda vez que su obra responde a un deseo básico: el de encontrar en la historia de la cultura un lugar que permita la aparición de una forma primaria e insuficiente del ser. Esta búsqueda ontológica en caso alguno se propone la totalidad como objetivo, guiada por la carencia produce el ser, debilitándolo (Vattimo, 1992). El viaje ocurre como una locura que esconde una lógica negativa, al contrario de la lógica positiva que busca apresuradamente interrumpir la locura del exilio por medio del arraigo en la tradición.

Me detendré sobre unas afirmaciones de Pérez Villalón. La primera de ellas señala que el escritor asume un tópico de la cultura literaria, en el cual el viaje implica una forma inicial de trasgresión del recinto de la cotidianidad, por lo tanto, una transfiguración de la experiencia. En su calidad de tópico, el viaje aparece en el horizonte imaginario occidental como un símbolo de ruptura y de exposición del capital ontológico que alimenta otras formas de transgresión que suponen una alternativa para la experiencia sin tener necesariamente que abandonar el espacio físico. Ahora, lo interesante en lo señalado por Pérez Villalón viene a continuación:

La contraparte a esta experiencia eufórica del viaje, sin embargo, era siempre la constatación de que el desplazamiento no sirve de nada, de que la naturaleza humana es igualmente corrupta en todas partes, que la experiencia del viaje es finalmente tan banal y fatigosa como cualquier otra (Pérez Villalón, 2004: 51-52)9.

Esta cita lleva a Pérez Villalón hacia unos versos del poema "Kandinsky 1904 " incluido en $P E$, en los cuales se busca confirmar esta naturaleza más bien pesimista en relación a las transformaciones que posibilita la partida. El viaje mismo y su invitación al asombro se funden en lo que deja de ser,

\footnotetext{
${ }^{9}$ Similar intuición se desprende de la escritura de Constantino Cavafis en su poema "La ciudad", poema que sirve de epígrafe al libro Las cartas olvidadas del astronauta del chileno Javier Campos (1990) -libro en donde se problematiza de forma intensa la problemática del destierro histórico y existencial. Transcribimos el poema íntegro: "Dices: "Iré a otra tierra, hacia otro mar $/$ y una ciudad mejor con certeza hallaré. / Pues cada esfuerzo mío está aquí condenado. / Y muere mi corazón/lo mismo que mis pensamientos en esta desolada languidez. / Donde vuelvo los ojos sólo veo / las oscuras ruinas de mi vida / y los muchos años que aquí pasé o destruí". // No hallarás otra tierra ni otro mar. / La ciudad irá en ti siempre. Volverás / a las mismas calles. Y en los mismos suburbios llegará tu vejez; / en la misma casa encanecerás. / Pues la ciudad es siempre la misma. Otra no busques - no la hay- / ni caminos ni barco para ti. / La vida que aquí perdiste / la has destruido en toda la tierra".
} 
justo en el momento en el que alcanza su realización plena. Lo mismo y su encuentro con lo otro se des-realiza en la certeza precaria sobre la que se construye lo mismo. Dicho de otro modo, el viaje se sostiene en la imposibilidad esencial del desplazamiento como instancia transformadora, que en el imaginario poético lihneano corresponde al "imposible exilio", enunciado que soporta al otro: "Nunca salí de horroroso Chile". De esta forma la cifra final de "Kandinsky 1904": "No bien partía un barco de oro de la orilla / cuando ya no era orilla ni barco ni partía." (Lihn, 1986: 16), alumbra la imposibilidad que porta la ausencia, la de ir hacia lo mismo en la constante barrera de desprenderse, de desasirse, escepticismo latinoamericano demasiado escéptico a fin de cuentas.

Es cierto que la impugnación del viaje como acto transformador constituye a su vez un tópico de la cultura. Sin embargo, para el escritor latinoamericano el desplazamiento aparece como condición básica y urgente. La necesidad, digamos imperiosa, de experimentarlo tanto eufórica como disfóricamente. Este aspecto pesimista dominante, en el cual el viaje no redime al errante, puede transformarse mediante la subjetivación de tal experiencia, pasar del hecho concreto, histórico y real, para acceder a la revelación de su idea. Como señala Pérez Villalón:

Una alternativa ante esta desoladora perspectiva es la subjetivización de la experiencia de viajar: para encontrar la experiencia no haría falta en verdad desplazarse, sino dejarse impresionar, abrir los sentidos a las sorpresas que nos puede deparar la propia patria (Pérez Villalón, 2004: 52).

Esto último no parece válido del todo. El viaje, para un escritor como Lihn, es en parte esa subjetivación, pero sólo en la medida que éste como tal ocurra. El viaje debe ocurrir para que lo otro ocurra, para que el plano ideológico se altere. Lo mismo persiste subjetivado, pero lo otro está ahí, iluminado de pronto por la mirada del sujeto errátil.

\section{1986: PENA DE EXTRAÑAMIENTO}

La presencia de este libro en la bibliografía lihneana, no parece ser tan importante o clave como la de otros libros del autor, los que ciertamente han recibido mayor atención crítica. Este libro, que en realidad es una solución editorial a un conjunto mayor de escritura circunstancial, situada, está cifra- 
do en el enunciado Pena de extrañamiento ${ }^{10}$. La situación de esta expresión está determinada por su naturaleza jurídica, primero, y además, a partir del mismo enunciado, por extrañamiento de la palabra pena, que agrega el contenido emocional que damos a esa expresión: pena como castigo, pero también como sensación. Lo mismo ocurre en el caso de extrañamiento, palabra que funciona como sinónimo de exilio, pero que oculta también la noción de extrañeza y de memoria, es decir "recuerdo" ligado al significado del verbo extrañar. Pena de extrañamiento es un enunciado que puede leerse a través de esta riqueza semántica, pero más allá de estos juegos de lenguaje, lo cierto es que se hace evidente una oscilación de la subjetividad por medio de la expresión entre estos dos extremos semánticos, entre estas dos proposiciones de sentido sin establecer en ninguna de ellas un punto de arribo definitivo. Al respecto Pedro Lastra señala lo siguiente:

La fórmula legal, que supuestamente atenúa la violencia de la frase "condena de destierro", presta hora a la última poesía de Lihn el servicio de su polisemia: pena y extrañamiento significan varias cosas; pero en la poética teatral de Bertol Bretch la palabra "extrañamiento" se refiere a la distancia que hace posible la reflexión crítica del espectador. Aquí, bajo la especie contradictoria de una "emoción intelectual", y potenciado por su alianza con las connotaciones de la "pena", el extrañamiento apunta a la situación del sujeto errátil que habla en estos poemas en distintos espacios, (...) (Lastra, 1986: 6).

La claridad de Pedro Lastra nos orienta en la espacialidad construida por Lihn. Primero, el que la subjetividad de estos textos se realice en un flujo de carácter crítico-reflexivo, asunto que el autor, sabemos, llevó hasta extremos impensados. La poesía de Lihn logra generar una textualidad poética en donde la escritura creativa se vincula con la naturaleza del pensamiento crítico, generando lo que el mismo Lastra llama "emoción intelectual". El segundo aspecto que llama nuestra atención en la cita es la presencia de un "sujeto errátil" que se mueve por distintos espacios a través de diversos poemas dominados por esta "emoción intelectual". De esta forma, la imagen de la portada refuerza los signos ocultos en el enunciado Pena de extrañamiento. El interior de un vagón de metro que muestra a su vez el frío exterior de un grupo de personas que comparten ese espacio interior, en lo que se supone

\footnotetext{
${ }^{10}$ Según señala Pedro Lastra en una reseña sobre el libro "con la expresión 'pena de extrañamiento', el pintor Oscar Gacitúa tituló un ensayo, inconcluso o suspendido que recorría estos diez años de la poesía de Enrique Lihn" (Lastra, 1986: 6-7).
} 
un viaje. Cada pasajero parece estar absolutamente separado del otro, como absorto en sí mismo. Este contenido se ve potenciado por el único pasajero que está, por así decirlo, en una posición contraria a la totalidad. Tanto que destaca por estar de pie en una zona de la imagen en que todos están sentados y en la misma dirección, enfrentados. La imagen se fuga a través de ese personaje que mira por la ventana. Como si se exiliara de ese exilio exterior que ocurre en el interior del vagón, posibilitando una fuga mayor, la que se cifra en una diferencia física radical. Pena de extrañamiento que bien puede ser recibida o también asumida como decisión, como riesgo. Coger el exilio, asirse de él materializándolo, subjetivándolo, crea un extrañamiento interior, distinto al que aparece determinado por las circunstancias socio-históricas. Se sabe que el poeta no padeció el exilio histórico-político, sino que se quedó. Pero en la reflexión lihneana, el exilio aparece como una forma interior determinada por la configuración cultural del intelectual latinoamericano y su relación con la tradición occidental. El exilio viene primero desde afuera, desde el poder y luego se padece, ahora recibir el exilio de uno mismo genera un pliegue impensado, en el cual la subjetividad instiga contra el sujeto y lo empuja al extremo de sí mismo. Lo anterior se articula a través del doble y el hueco, la imagen subjetivada del pliegue y el sujeto:

Ese doble abrirá en mí un hueco que yo mismo no podría llenar con las anotaciones de mi diario de viajes (Lihn, 1986: 10).

El viaje que se recoge en $P E$ está atravesado, entonces, tanto por la nostalgia como por la mirada irónica. El cuaderno contiene la mirada, la escritura, las impresiones que causa en su condición bastarda la hiperciudad en la que siempre se está de paso. La nostalgia se presenta en relación con lo que el mismo Lihn ha llamado el anti-origen. Entendiendo que el sujeto está imposibilitado de arraigar en el espacio sobre el cual erra. Y aquí errar quiere decir también mantenerse en una condición equívoca; pero, de igual forma, mantenerse en movimiento, en un ir nómade que ni busca ni quiere el arraigo como forma correcta para el ser. En la reflexión de Levinas sobre Blanchot, el autor señala en relación con la condición errátil lo siguiente:

El nomadismo no es una aproximación al estado sedentario. Es una relación irreductible con la tierra: una estancia sin lugar. Ante la oscuridad a la que llama el arte, como ante la muerte, el "yo», soporte de poderes, se disuelve en un «se» anónimo a través de una tierra de peregrinaciones. Yo 
de Nómada eterno que se enraíza en su marcha y no en un lugar propio, en las fronteras de la no-verdad, en un reino que se extiende más lejos que lo verdadero. Verdad condición de errancia, errancia condición de verdad (Levinas, 2000: 42).

Por lo mismo, el sujeto errátil de los poemas de Lihn está, a su vez, en condiciones de experimentar la ciudad a partir de su cotidianidad ominosa, de su errancia. Es decir, esta subjetividad en tránsito no sólo ve la ciudad que es posible reducir al rectángulo de la postal, sino que también aquello que excede los límites de la impresión fotográfica. Esto que excede la imagen, el exceso de realidad que intuye la escritura son los materiales que, sumados al material de la experiencia de un intelectual latinoamericano, conforman cada una de estas observaciones motivadas por un ojo en pleno desarraigo. Esta subjetividad en situación, en circunstancia transforma en texto lo que la ciudad expone, pero también lo que oculta este sujeto:

(...) sujeto errátil que habla en estos poemas en distintos espacios, generando una dialéctica fantasmal entre los textos; un sujeto que se desrealiza en los lugares de paso, nunca habitados por él (Lastra, 1986: 6).

Este exceso de realidad del que se logra dar cuenta mediante anotaciones, suspende, o bien ralentiza la temporalidad, permitiendo la articulación crítica de los espacios por los cuales la subjetividad se desplaza, no como visitante o como turista, sino como una fantasma que no se deja ver, pero que ve los bajos fondos que sostienen la ciudad en su exceso. De esta manera, Chile, Santiago -la ciudad sitiada, la ciudad de "Alicia en el país de las pesadillas" ${ }^{11}$, la medio-ciudad, la copia defectuosa, la ruina y el nido- aparece como un dato escalofriante en el interior impaciente del fantasma que intenta agenciar con la "megalópolis" habitada, a su vez, por fantasmas. ¿Qué mira el fantasma poseído por esta infralengua con la cual se autoriza un diálogo feroz consigo mismo y las ruinas de su memoria? Imágenes, eso mira: "Me dejo atar, fascinado por ella / A los recuerdos del presente" (Lihn, 1986: 7). En lo dicho queda en evidencia que hay una cifra fantasmal que se disuelve en el paisaje mirado: la ciudad vigilada, la ciudad de las pesadilla en la que "(D)isparan en la noche" (Lihn, 1986: 57), y en la que la "rasguñadura de la Edad Dorada / (es) llaga luego y ahora podredumbre" (Lihn, 1986: 49), como se piensa en el poema "De lo mis-

${ }^{11}$ Uno de los últimos poemas de PE. 
mo". Chile, a través del símbolo ominoso de la ciudad de Santiago, que es "El vaciadero", como la denomina en A partir de Manhattan (1979), que es "Un coto de caza del tamaño del país" (Lihn, 1986: 57) como se señala en $P E$, aparece entonces como un holograma de terror sobre el pavoroso exceso de la ciudad norteamericana. Esta suma de elementos sedimenta sobre la óptica poética sobre la que se agita la subjetividad en su ansioso trabajo de desciframiento del espanto. Las ramificaciones del poema clave en la escritura total de Enrique Lihn "Nunca salí del horroroso Chile" ( $A$ partir de Manhattan, 1979: 53) se extienden y retienen en sus nudos las posibles fugas de la subjetividad empeñada en el desarraigo. De esta forma los vivos, en su compleja relación con la existencia alcanzan la paz sórdida de la que no disfrutan los muertos. Expulsados también de la noche, los habitantes de "el país de las pesadillas" duermen en paz, mientras afuera pasan los oscuros "peregrinos de Emaus". En este clima obsceno, anunciado ya en el poema que inicia el libro, el poeta resuelve nuevamente las razones de la escritura, el por qué escribí, ahora escrito "con el canto de la goma de borrar" (Lihn, 1986: 57). Si bien se ha estado en el exceso indiferente de la hiperciudad, en la que las subjetividades son triviales objetos en una gigantesca obra de arte, el sujeto no logra desprenderse de la indiferencia sorda de la "medio ciudad" en la que arraiga roto, en la que la subjetividad viene a ser "Alma sin cuerpo en sola voz fundada" (Lihn, 1986: 56). La temporalidad que rige malamente los múltiples tejidos temporales en los que se desplaza equívoco el sujeto, es la de un país sometido a una tiranía que obscenamente se va regularizando, normalizando: Chile hacia fines de los 70:

Cristo en la Morgue, víctima de la sustitución de su cuerpo Los cadáveres que pierden su derecho a la identidad ante sus reencarnaciones fraudulentas que circulan por el mundo de de los negocios, en la ciudad rápidamente roídos por la cal en el pozo El sol negro de la próxima primavera que llega cargada de frutos descompuestos El lobo que duerme junto a la majada No son figuras sino cosas que pasan en el seno de un mundo desfigurado cuando la realidad es un espejo de feria (Lihn, 1986: 51). 


\section{LA MUSA DE LA CALLE, EL HOSPITAL Y LOS MUSEOS}

Uno de los temas centrales que desarrolla la escritura de $P E$ es el de la imagen como constituyente fundamental del imaginario cultural de la baja modernidad. De esta forma, lo que resulta interesante es la manera en la que se encuentran la imagen de la alta cultura (la pintura, la fotografía artística, la arquitectura, la instalación) y la imagen como testimonio social, como producto comercial incluso, y que es la forma de representación dominante en la baja cultura (el cine comercial, la publicidad, la televisión, la música pop, incluso la fotografía comercial -las postales-). Es así como el escenario por el cual se mueve la subjetividad errátil no es nunca la realidad social que el sujeto extraña y que aparece allí velada por la imagen, generando en el observador esta impresión fantasmática, según Lastra: “(...) la imagen tiene el mismo rango ontológico que la realidad, la que puesta así en crisis se revela en su carácter fantasmático" (Lastra, 1986: 6).

Este contenido de $P E$ es el eje fundamental sobre el cual se disponen los diferentes motivos textuales; las series poemáticas están orientadas por la fuerza ontológica de la imagen, una ontología debilitada, o bien en las postrimerías de la mirada ontológica. Lo que la subjetividad intenta es orientar la escritura hacia la búsqueda de aquello que le permita concentrar la potencia existencial que lo moviliza y esto en la perspectiva de un saber que considera la naturaleza fragmentaria de la sociedad occidental. Los poemas posteriores a los dos textos iniciales son justamente concentraciones de la mirada sobre objetos de arte. Y en este sentido, en este periplo museológico, la ciudad ajena, la ciudad del otro, es también un gran museo, una obra de arte dinámica en donde lo otro es también un objeto de arte, sujetos que entran en situación de arte para quien tenga la capacidad de concentrar la mirada bajo el signo de una reflexividad dinámica y explosiva, es decir, a la que se pueda acceder cuando el evento de arte ocurra, en un presente que es ya memoria: - "recuerdos del presente" dice Lihn-. En otras palabras, la subjetividad no sólo se relaciona reflexivamente con el objeto que la cultura y la tradición -el canon- establecen como el objeto destinado a la reflexión, sino que también lo otro, lo desconocido, la diferencia son percibidos bajo esta primera extrañeza. De acuerdo a lo anterior, quien mira captura aquello ausente y lo reflexiona, produciéndolo. Esta naturaleza estética, que la modernidad consagró en el objeto, privándole así de poder intervenir efectivamente sobre la realidad, se desplaza hacia una zona no histórica, sino que de una extraña fuerza cotidiana. Este destino del objeto de arte -su ser arte- Blanchot lo entiende 
como porvenir de excepción, aquello que posibilita que la obra surja de entre el murmullo del lenguaje humano y se separe, arrastrando consigo a la subjetividad. Entre ambos, obra y subjetividad, aparece esto raro que es el espacio literario, esta suerte de intimidad en la que el ser se profundiza. La obra en su constante fuga arrastra el ser hacia esta profundidad en la que el ser del objeto-arte resplandece. En esta profundidad o espesura ambos -obra y subjetividad se iluminan, no en el sentido ilustrado y esto es lo interesante- se hacen aparecer en una relación impensada. Entonces el museo al que Lihn accede como cualquier ciudadano - pero no exactamente como cualquiera, ya que accede desde un saber específico, especializado y desde una condición particular, es decir, marginal-latinoamericana- es una producción de la mirada, un museo que se está levantando constantemente a partir de la mirada en desarraigo. Pero el museo es también la calle, los panoramas cotidianos vistos a través de "un ojo que piensa lo que mira" y que luego lo produce como imagen. Este objeto pro-ducido, que es traído desde esa zona todavía de significantes, y a la cual se le piensa un sentido, tiene un efecto reflexivo: la subjetividad logra acceder a $l o$ otro como lo mismo. La fuerza crítica que hay en la mirada que se produce en $P E$ tiene una naturaleza clínica, la subjetividad se abre y se expone permitiendo en ese movimiento que el yo sea narcotizado por el afuera, por fuerzas ajenas a la bella interioridad, que la poesía moderna consagra como un logro del romanticismo ${ }^{12}$. Este gesto constituye una intimidad, un interior en el afuera. El hospital como signo de una extraña forma de salud, una especie de consagración de la enfermedad como condición, en la que el sujeto está plegado sobre el "sucio secreto de la muerte". La imagen de una ciudad enferma es recurrente en la poesía de Lihn, sobre todo en su poesía de viaje, en donde las viejas ciudades vienen a ser espacios bellamente enfermos de historia, "visitar enfermos". Como si en ese viaje el sujeto fuese a estudiar la sintomatología que padece culturalmente, su mal congénito, etc.

El primer poema da título al libro. En él la subjetividad establece y fija el momento de la partida de la ciudad ajena como una instancia reflexiva. La primera afirmación es el hecho contradictorio o bien paradojal de irse y no irse: "no me voy de esta ciudad con la resignación de los visitantes /

${ }^{12}$ El romanticismo y sus formas más cercanas en el canon occidental, como el simbolismo y el realismo o bien la interioridad social presente en el naturalismo, incluso algunas realizaciones de la vanguardia no son sino formas de conservar el interior a salvo del sin sentido cotidiano que domina el exterior. Lo que se presiente, desde el momento en que la ciencia establece en la literatura una punta de arena, es el hecho evidente que en el exterior hay una fuerza voraz, el afuera. 
en tránsito / me dejo atar, fascinado por ella / a los recuerdos del presente" (Lihn, 1986: 7). En la inminencia del viaje de regreso, la subjetividad expone su interioridad temporal a la memoria de la ciudad. Este agenciamiento ocurre por un efecto de anulación de la temporalidad, lo que con Blanchot entendemos como la fascinación por la ausencia de tiempo. El presente se hace recuerdo y permite que el sujeto se transforme, por un efecto de lenguaje, en una suerte de imagen fantasmática. Pero dicho efecto sólo cobra sentido en el imaginario particular, en el diario de viaje, que contiene a esta escritura transitoria. Este hecho es fundamental para entender la forma en que Lihn se aproxima a la obra, esto es, mediante "elaboraciones del deseo" (Lihn, 1986: 7) que se actualizan por medio de una escritura del desarraigo. La poesía de viaje de Enrique Lihn tiene esta dirección inevitable. La presión persecutoria señalada por Maurice Blanchot se realiza en Lihn de una forma que arrastra una desdicha básica ${ }^{13}$, y que es la insuficiencia del lenguaje, pero también la constatación contradictoria de que la poesía, la literatura, ese más allá del lenguaje, no logre interferir efectivamente en la realidad. Al revés de lo que ocurre con la circunstancia que sí opera sobre el lenguaje poético, determinando el radio de una impresión que se produce horadando el espacio de la circunstancia. Recordemos que el poema "Pena de extrañamiento" se construye sobre una anécdota, la compra de un haz de fotografías antiguas:

Esos antepasados eran los míos, pues aunque los adquirí a vil precio no tardaron, sin duda, en obligarme a la emoción ante el puente de Brooklyn como si Manhattan, que se enorgullece de volatilizar el pasado conservándolo en el modo de la instigación a desafiarlo fuera mi ciudad natal y yo el hijo de esos antiguos vecinos de los que la voz gutural

hace irrisión, y el martillo (Lihn, 1986: 7).

La ficción que se construye sobre la base de un hecho concreto, un dato de la realidad, abre el lugar para enunciar la carencia básica del sujeto, su doble no pertenencia, la constante incomodidad del arraigo que le hace reconocer este apego irracional por el pasado, el cual se expresa en la memoria disfuncional del sujeto latinoamericano. El espacio hipermoderno renuncia

\footnotetext{
${ }^{13}$ Desdicha y constatación que es fundamental en la poesía del autor a partir del poema "Porque escribí" que pertenece al libro La musiquilla de las pobres esferas (1969).
} 
a la memoria y con ello arrastra, en una suerte de flujo horroroso, al sujeto que quiere justamente producir memoria y disponer las condiciones para un arraigo satisfactorio:

La isla dispone de fantasmas artificiales

Con que llenar los huecos de la contra-historia

Ellos ocupan en la memoria, con la naturalidad que ésta se permite

En relación a la nada

El lugar de los verdaderos ausentes: caras que vi en las bouffonier del Soho /(...) (Lihn, 1986: 8).

La certeza que el poema desliza entre los versos se produce, justamente, por una oscilación entre imágenes, las de la ciudad "real", en la que habitan los "veros vecinos de / Washington Square", y también las imágenes de la experiencia que aparecen superpuestas sobre el panorama, las imágenes que se levantan e iluminan el saber del sujeto que las reflexiona. Así, muchos de los enunciados producidos en el poema se mueven en dos direcciones, el eje es la subjetividad, que aparece entonces doblemente iluminada, primero, por este deseo de arraigo y, luego, por el imposible desarraigo que pareciera ser absoluto. Federico Schopf señala al respecto:

Su sensación -casi su deseo de arraigo- quería ser la condición de su arraigo en otra parte construida por él y otros como él. El poeta -junto a la desacralización de su oficio- llevaba marcadas las huellas más modernas, de su soledad y falta de lugar en el mundo (Schopf, 1986: 51).

No se trata sólo de que surja de entre la textualidad la evidencia de su no-pertenencia, sino de que la subjetividad; sin embargo, ha encontrado un lugar y entablado con él un diálogo reflexivo al que incluso arrastra la naturaleza de su "imposible exilio" como dice en el poema "Nunca salí de horroroso Chile". La imagen que hay detrás de la imagen es un lugar que el sujeto puede incorporar al texto, intelectualizarlo y emocionalizarlo ${ }^{14}$. Las acciones contrarias son, sin embargo, una acción: irse y no irse, ser y no ser, conocer y no conocer, entre otras acciones que se encuentran a lo largo del texto y que conforman un movimiento hecho de contrarios, la reconciliación de lo que se excluye, una forma que ocurre simultáneamente. Lo simultáneo entonces es un constituyente esencial en la escritura

${ }^{14} \mathrm{Si}$ la expresión es adecuada. 
de Lihn. La ocurrencia de algo en un instante de lenguaje, en donde los tiempos, por ejemplo, ocurren al mismo tiempo, al margen del rigor gramatical; o bien, los espacios que se tocan y se confunden, o las sensaciones diversas que ocupan un mismo cuerpo en un instante. Hay cierta zona de convergencia que la circunstancia del observador permite, la aparición del doble, el negativo, la mixtura, la sombra: "ese doble abrirá en mí un hueco que yo mismo no podría llenar / con las anotaciones de mi diario de viajes" (Lihn, 1986: 10). Fenómeno de ubicuidad, la intuición de que la escritura es un gesto que deja de ser propio, transforma y desactualiza la carga autorial del gesto poético, reuniendo una misma forma en una conciencia que permite pensar-se en espacios lejanos entre sí, pero que la subjetividad ocupa al mismo tiempo. Esto último es fundamental en la comprensión del primer texto: Pena de extrañamiento se configura como una forma poética testimonial, es decir, el poeta deja, a partir de la serie de anécdotas que se encadenan y se afectan a lo largo del texto, constancia del abandono de la ciudad. La circunstancia in-significante de la partida, que aparece como una dato inactual, aislado mediante el uso de paréntesis: "(borrado ya del tiempo el día de mi partida: dos de enero de mil novecientos ochenta y uno)" (Lihn, 1986: 9). A pesar de la dificultad y la complejidad textual, el poema no integra desordenadamente los datos de la experiencia, más bien genera un orden emocional, mediante el cual logra afinar la reflexión sobre la temporalidad, sobre la pertenencia, sobre la memoria, sobre la condición transitoria del sujeto en el escenario occidental de la baja modernidad, condición temporal que no sólo se reduce a su-ceder, sino que es in-actual e in-significante. Nadie está en condiciones de experimentar al otro en su profundidad. El sujeto pasa por el otro a velocidades que no dejan lugar a la comprensión absoluta. La incomprensibilidad del otro impide que los sujetos experimenten la afectividad, que en el caso de la subjetividad de estos poemas sigue siendo un asunto: "No me voy de esta ciudad sin haber amado aquí / a la mujer que conocí y no conocí ni haber agotado la vida conyugal / reflotando en el negocio de plantas y antigüedades" (Lihn, 1986: 7). Esta disposición fantasmática con la cual se construye el poema, actualiza a partir de su relación con la hiperciudad, el conflicto velado con las llamadas "medio ciudades". El poema mismo no es sino la constatación reflexiva de este movimiento inefable. El regreso al "horroroso Chile" del cual no se puede "desprender". 


\section{REFERENCIAS}

Blanchot, Maurice. 1969. El espacio literario. Buenos Aires: Editorial Paidós.

Campos, Javier. 1990. Las cartas olvidadas del astronauta. Miami: Hallmark Press.

Fuenzalida Villarroel, Daniel. 2005. Enrique Lihn entrevistas. Santiago, Chile: J.C. Sáez Editor.

Lastra, Pedro. 1986. "Pena de extrañamiento", en ICTUS informa: un espacio de libertad / ICTUS. Santiago: ICTUS, v. No 10, pp. 6-7. Ediciones. . 1990. Conversaciones con Enrique Lihn. Santiago, Chile: Atelier

Levinas, Emmanuel. 2000. Sobre Maurice Blanchot. Madrid: Editorial Trotta S.A.

Lihn, Enrique. 1963. La pieza oscura. Santiago: Editorial Universitaria. . 1966. Poesía de paso. La Habana: Casa de Las Américas. 1969. La musiquilla de las pobres esferas. Santiago: Editorial Universitaria.

1977. París, situación irregular. Santiago: Ediciones Aconcagua. 1979. A partir de Manhattan. Valparaíso: Ediciones Ganymedes. 1986. Pena de extrañamiento. Santiago: Sinfronteras. 1987. Mester de juglaría. Madrid: Hiperión.

1987. La aparición de la Virgen. Santiago: Cuadernos de Libre (E)lección.

1989. Diario de muerte. Santiago: Editorial Universitaria.

O'Hara, Edgar. 1996. Isla negra no es una isla: el canon poético chileno a comienzos de los ochenta; entrevistas. Valdivia: Editorial Barba de Palo.

Parra, Nicanor. 1972. Artefactos. Santiago: Ediciones Nueva Universidad.

Pérez Villalón, Fernando. 2004. "Variaciones sobre el viaje (dos viajeros ejemplares: Mistral y Oyarzún)", en Revista Chilena de Literatura 64, pp. 47-72.

Schopf, Federico. 1986 "Pena de extrañamiento", en Pluma y Pincel 18. Santiago: Artes y Letras de América, p. 51.

Valdés, Adriana. 2008. "Enrique Lihn: Santiago, París, Manhattan", en Revista Chilena de Literatura 72, pp. 89-113.

Vattimo, Gianni. 1992. Más allá del sujeto. Nietzsche, Heideger y la hermenéutica. Barcelona: Ediciones Paidós. 